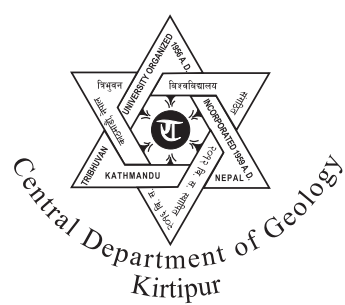

\title{
Lithostratigraphy and late Cenozoic fluvial styles of Siwalik Group along Kankai River section, East Nepal Himalaya
}

\author{
Prakash Das Ulak \\ Department of Geology, Tri-Chandra Campus, Tribhuvan University, Nepal
}

\begin{abstract}
This paper describes on lithostratigraphy as well as evolution of the fluvial styles in late Cenozoic Siwalik Group along the Kankai River section of east Nepal Himalaya. The Siwalik Group lies on the southern flank of the Himalaya, is composed of molasse sediments, which were derived from the rising Himalaya in the north. The group along the Kankai River section is lithologically divided into the Lower, Middle and Upper Siwaliks, in ascending order based on increasing grain size and lithology. The Lower Siwaliks is subdivided into the lower and upper members, whereas the Middle Siwaliks is subdivided into the lower, middle and upper members on the basis of the relative thickness of the sandstone and mudstone beds, frequency of occurrence of these beds, and grain size of sandstone. The Upper Siwaliks is subdivided into the lower and upper members based on the clast size in conglomerate and constituent of the Siwalik sandstone boulders in conglomerate.

Based on the lithology, assemblages of sedimentary structure and sediment body architectures, seven facies associations (FA1 to FA7) are recognised. These facies associations are closely related to each lithostratigraphic units of the area. The sediments of the lower and upper members of the Lower Siwaliks are products of the fine-grained meandering and flood flow-dominated meandering systems, respectively. The lower, middle and upper members of the Middle Siwaliks are interpreted as the deposits by sandy meandering, deep sandy braided and shallow braided systems, respectively whereas the lower and upper members of the Upper Siwaliks are the products of gravelly braided to debris flow-dominated braided systems, respectively.
\end{abstract}

\section{INTRODUCTION}

The Siwalik Group is delimited by the Lesser Himalaya to the north and Indo-Gangetic Plain to the south. The group is located between the Main Boundary Thrust (MBT) in north and the Frontal Churia Thrust (FCT), equivalent to the Himalayan Frontal Thrust (HFT) in south. The group is exposed in the southern frontal hilly areas called Churia Hills, and is frequently called the Churia Group (Fig. 1). The latter is comprised of fluvial sediments, which were deposited as a result of Neogene tectonics of the Himalaya (Parkash et al. 1980; Nakayama and Ulak 1999; Ulak and Nakayama 2001; Ulak 2004). As a whole, the stratigraphic succession shows the

Author's E-mail address: prakashulak@yahoo.com coarsening-upward (e.g., mudstone, sandstone and conglomerate) which reflects the rising Himalaya, while each fluvial succession shows the fining-upward succession.

The Siwalik Group is subdivided traditionally into three units, namely, the Lower, Middle, and Upper Siwaliks, in ascending order. But two- to six-fold arrangement of the Siwalik rocks is also acceptable. Lithostratigraphic units of the previous studies are summarised in Table 1.

The studies of evolution of the fluvial styles in the Siwalik Group by Parkash et al. (1980), Nakajima (1982), Willis (1993), Hisatomi and Tanaka (1994), Zaleha (1997), Khan et al. (1997), Ulak and Nakayama (1998), Nakayama and Ulak (1999), Ulak and Nakayama (2001), and Ulak (2004) showed that the meandering system was appeared at first in the Siwalik 


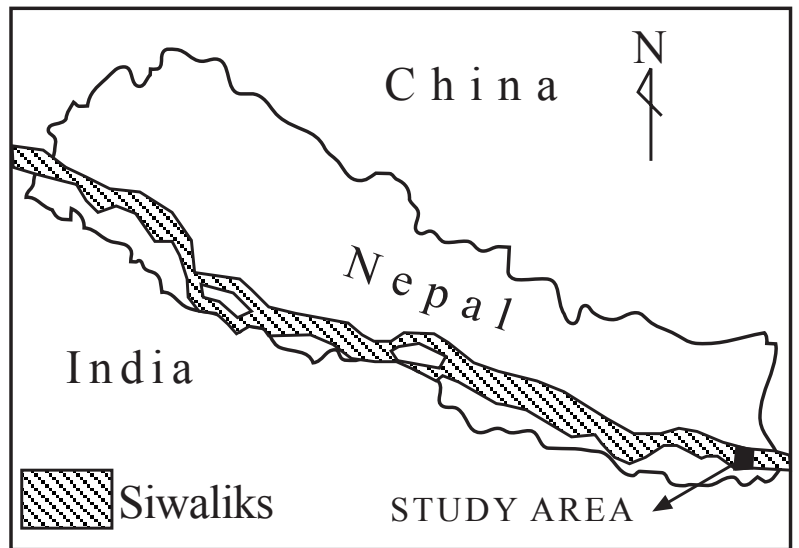

Fig. 1 Location Map of the study area.

basin and then it was changed into the braided system to finally gravelly braided system.

Sediments of the Siwalik Group were deposited during 16 to $1 \mathrm{Ma}$ in Nepal Himalaya (Tokuoka et al. 1986; Appel et al. 1991; Harrison et al., 1993; Gautam and Appel 1994; Gautam and Fujiwara 2000; Ojha et al., 2001. According to paleomagnetic time frame work, the meandering system changed into the braided system at 9.0 Ma, 8.2 Ma and 6.5 Ma in the Surai Khola section (west Nepal), Tinau Khola section (west-central Nepal), and Bakiya Khola section (central Nepal), respectively. Similarly, the braided system was changed into the gravelly braided system at 3.0 Ma, 2.5 Ma and 2.5 Ma in Surai Khola section, Tinau Khola section, and the Bakiya Khola section, respectively. These studies showed that change in fluvial system was caused by south propagating major thrust activities (e.g., MCT (Main Central Thrust), MBT, and CCT (Central Churia Thrust)) along the Himalayan front.

Details on lithostratigraphy and evolution of the fluvial styles of the Siwalik Group along the Kankai River section, east Nepal has not been carried out. The present paper deals with lithostratigraphy and the sedimentary environmental changes of fluvial styles on the basis of the facies associations.

\section{LITHOSTRATIGRAPHY}

Figs. 2 and 3 show the geological map and detailed columnar section of the study area. The lithostratigraphy of the Siwalik Group in the study area is summarised in Table 2. The Siwalik Group in the study area is lithologically divided into the Lower, Middle and Upper Siwaliks, in ascending

Table 1: Summary of the lithostratigraphy of the Siwalik Group of the Nepal Himalaya.

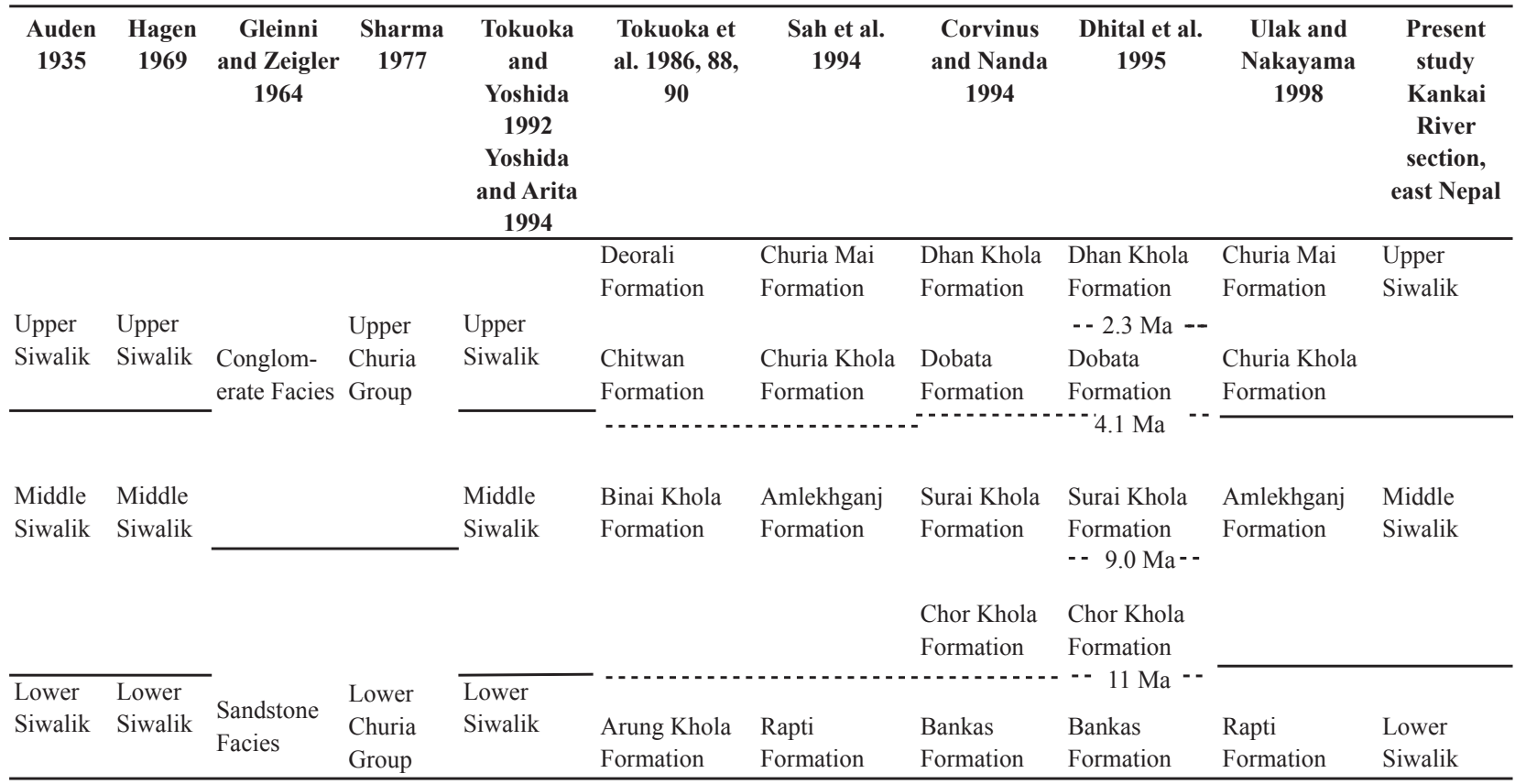


order based on the lithology and increasing grain size. The distribution of the Siwalik Group in this study area is divided into north and south belts by the Central Churia Thrust (CCT), and is equivalent to the Main Dun Thrust (MDT).

\section{Lower Siwaliks}

The unit is subdivided into the lower, middle, upper members based on the thickness of sandstone and mudstone beds and grain size of sandstone. This unit is well exposed along the Kankai River near Domukha village (Fig. 2) in the south belt and near Mahaguna village in the north belt.
The lower member is dominated by mudstone over sandstone to roughly equal proportion of sandstone and mudstone. This unit is characterised by very fineto fine-grained, greenish-grey sandstone interbedded with bioturbated, variegated mudstone. Mudstones range from 0.5 to $3 \mathrm{~m}$, whereas sandstones from 0.5 to $1 \mathrm{~m}$. The former often includes concretions. Sandstones are highly indurated due to presence of calcareous cementing materials, and have about 210 $\mathrm{m}$ total thickness.

The middle member constitutes roughly equal proportion of variegated to grey, bioturbated mudstone, and fine- to medium-grained, grey to greenish-grey,
Fig. 2 Geological Map with location of the columnar section of the Kankai River section, East Nepal.

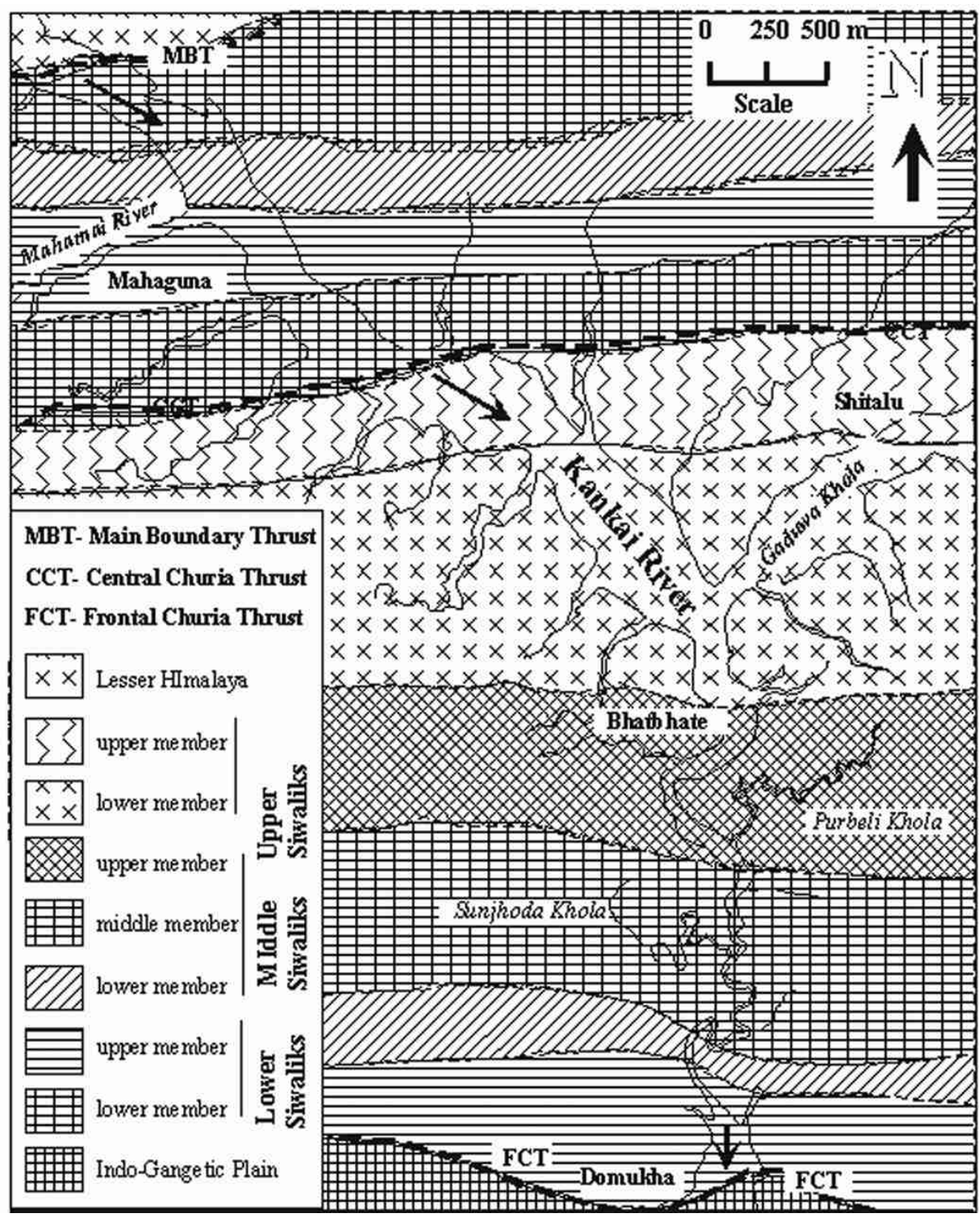

65 
calcareous sandstone. This member attains about 120 $\mathrm{m}$ thickness.

The upper member contains alternating beds of medium- to coarse-grained sandstone and variegated to dark grey mudstone. Sandstones are thicker than mudstone beds, and show "pepper and salt" like appearance in the top of the member. This unit reaches about $450 \mathrm{~m}$ in total thickness

\section{Middle Siwaliks}

The Middle Siwaliks is distributed along the Kankai River near the Sunjhoda Khola (Fig.2 in south belt and near the confluence between the Deu Mai Khola in north belt. This unit is subdivided into the lower, middle, and upper members based on the grain size of sandstone.

The lower member is represented by medium- to coarse-grained "pepper and salt" appearance sandstone with dark grey to black mudstone. Mudstones are comparatively thinner and less variegated than one of the Lower Siwaliks. Thickness of coarse-grained sandstones ranges from 1 to $5 \mathrm{~m}$, whereas muddy sandstones and mudstones range from 1 to $2 \mathrm{~m}$. Fining-upward succession of coarse sandstones to mudstones are distinct, and an individual succession is 2 to $10 \mathrm{~m}$ thick. This unit is about $340 \mathrm{~m}$ thick.

The middle member comprises thick bedded, coarse- to very coarse-grained, less indurated "pepper and salt" sandstone and grey mudstone. Sandstones are commonly multi-storied and are 2 to $15 \mathrm{~m}$ thick, whereas mudstone beds are 2 to $3 \mathrm{~m}$ thick. Finingupward sequence ranges from 5 to $10 \mathrm{~m}$. This unit attains about $600 \mathrm{~m}$ thickness.

The upper member is distinguished by very coarsegrained to pebble bearing sandstone, and reaches $2,100 \mathrm{~m}$ in total thickness. Sandstone is loose and commonly forms multi-storied beds. Pebbles in the sandstone are rounded to subrounded which are originated from the Lesser Himalayan terrain. Each fining-upward sequence is 5 to $15 \mathrm{~m}$ thick.

\section{Upper Siwaliks}

This unit is exposed along the Kankai River between Shitalu village and the Garduwa Khola in south belt (Fig. 2), and is divided into the lower and the upper members. The lower member is represented by well sorted, pebble- and cobble-conglomerate associated with reddish brown sandstpme and dark grey mudstone The clasts of the conglomerate are rounded to subrounded and show slight increase in size toward the younger succession. Crude crossbeddings occur throughout the unit. Imbrication of clasts is also observed in all the horizons. Conglomerate bed is 5 to $20 \mathrm{~m}$, while mudstone and sandstone beds are 0.5 to $1.5 \mathrm{~m}$ thick. Fining-upward successions are frequently observed, and their thickness is about 5 to $25 \mathrm{~m}$, and attain $1,100 \mathrm{~m}$ in total thickness.

The upper member is characterised by disorganised, loose, boulder-sized conglomerate with grey sandstone and mudstone. This unit contains typically the Siwaliks sandstone boulders. Fining upward successions are rarely developed with 7 to $10 \mathrm{~m}$ thickness. This unit is well exposed along north of Shitalu village and reaches thickness more than $500 \mathrm{~m}$.

\section{SEDIMENTARY FACIES ANALYSIS}

Representative detailed columnar sections (Fig. 3 ), which show typical fluvial autogenetic fining upward successions were prepared and studied. Categorization of the facies associations was based on nature of lithology, assemblages of sedimentary structure and sediment body architectures. Miall's (1978, 1985, and 1996) lithofacies code and architectural elements were followed. Dominant and minor lithofacies types and characteristic architectural element are shown in Table 3.

\section{FA1-Facies Association}

Facies association (FA1) is represented by dominance of bioturbated, thick bedded mudstone (Fm, Fr, Fsm; 0.5 to $2 \mathrm{~m}$ thick) interbedded with finegrained, greenish-grey, calcareous sandstone ( $\mathrm{Sr}, 0.2$ to $1.0 \mathrm{~m}$ thick) and sometimes thinly laminated mudstone (Fl) beds. Each fining-upward succession starts from trough cross-bedded sandstone $(\mathrm{St})$ at base to mudstone at top, and is about 2 to $5 \mathrm{~m}$ thick. It is also characterised by the presence of paleosol (P; 1 to $2 \mathrm{~m}$ thick) at the top of the sequence. The mudstones and the fine-grained sandstones are highly variegated. Sandstone beds have a sheet-like geometry, and are commonly composed of slightly muddy sands. 

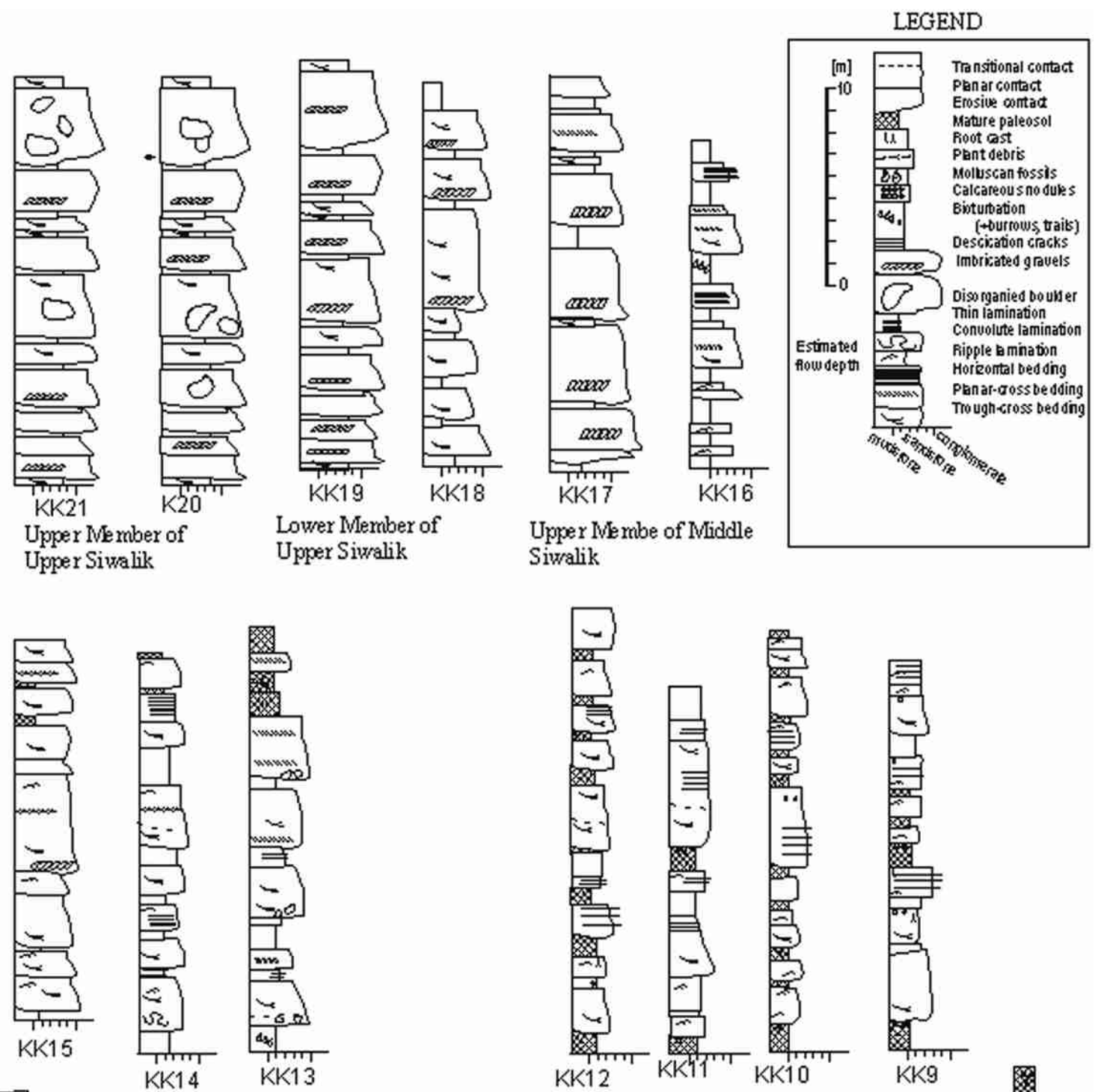

Upper Membe of Middle Siwalik
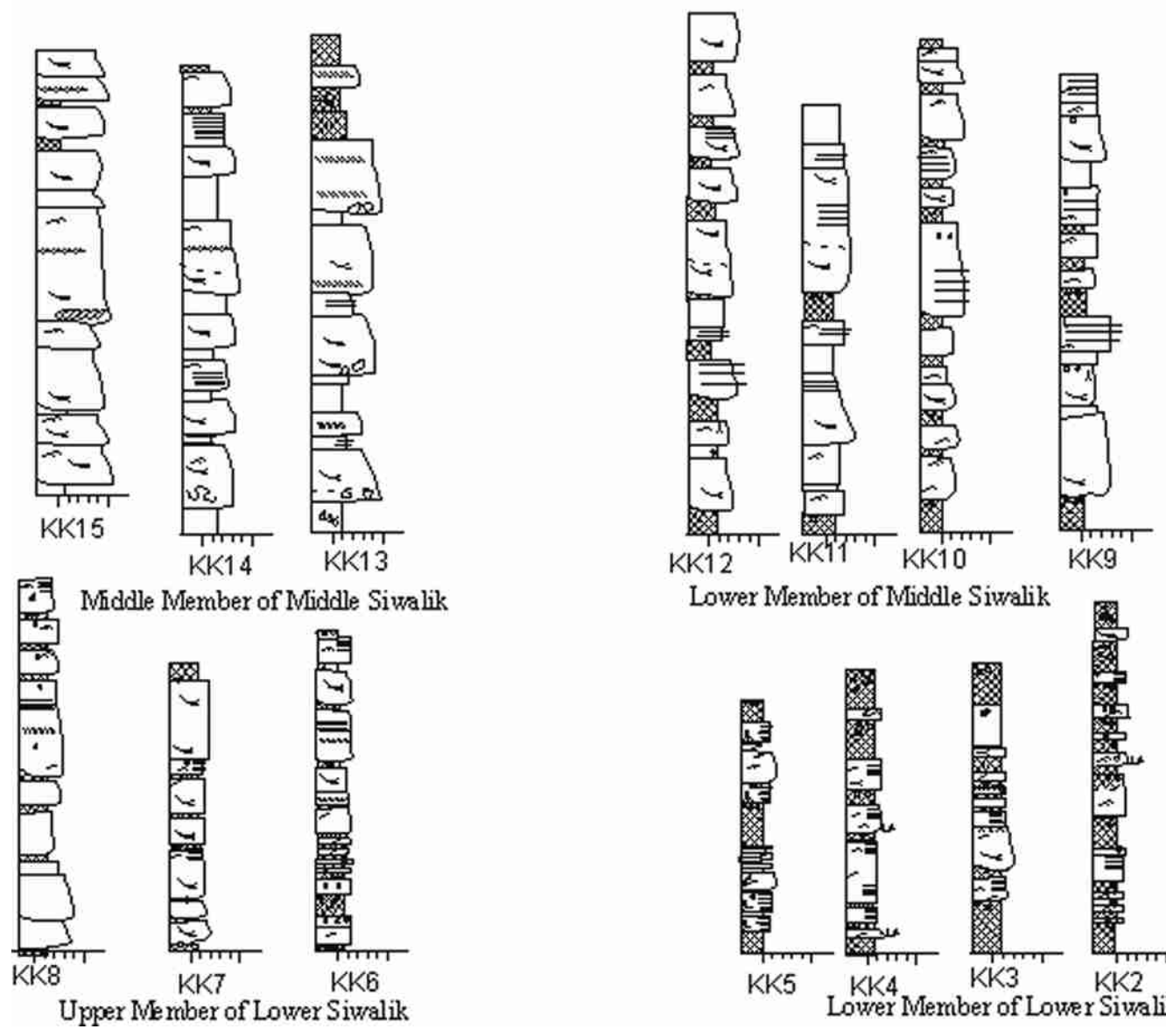

Lower Member of Middle Siwalik

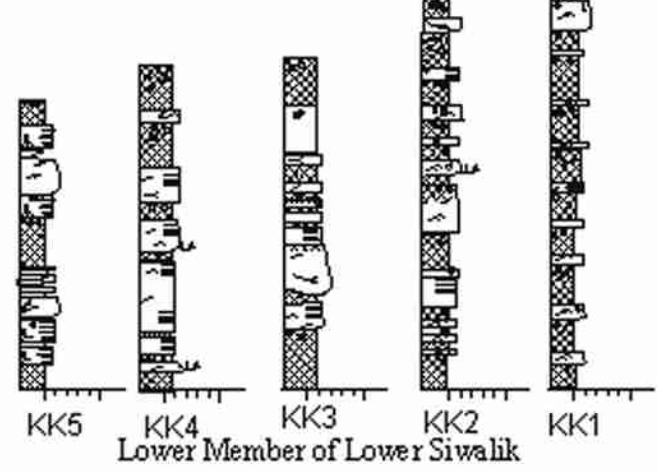

Fig. 3 Representative facies associations of the Kankai River section, East Nepal. 
Table 2: Lithostratigraphy of the Siwalik Group along the Kankai River section, East Nepal.

\begin{tabular}{|c|c|c|c|}
\hline & Stratigraphy & Thickness (m) & Lithological characteristics \\
\hline \multirow{2}{*}{ 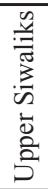 } & upper member & $450+$ & $\begin{array}{l}\text { Poorly sorted, matrix supported boulder-sized, loose conglomerates and lenses of sands. } \\
\text { Sandstone boulders are derived from the Siwalik Group itself. }\end{array}$ \\
\hline & lower member & 1500 & $\begin{array}{l}\text { Well sorted, clast supported, cobble-pebble sized conglomerates. Almost clasts of } \\
\text { conglomerate are from the Lesser Himalayan terrain. }\end{array}$ \\
\hline \multirow{3}{*}{ 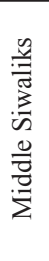 } & upper member & 1000 & $\begin{array}{l}\text { Thick bedded, coarse- to very coarse-grained, friable, "pepper and salt" sandstone with } \\
\text { pebbly sandstone. }\end{array}$ \\
\hline & middle member & 1700 & $\begin{array}{l}\text { Thick bedded, coarse- to very coarse-grained, "pepper and salt" sandstone with dark grey } \\
\text { mudstone. Sandstones are moderately indurated. (sst>>mst) }\end{array}$ \\
\hline & lower member & 400 & $\begin{array}{l}\text { Medium- to coarse-grained sandstone with dark grey mudstone. "Pepper and salt" sandstone } \\
\text { are found in which the amount of biotote flakes are less. (sst>ms) }\end{array}$ \\
\hline \multirow{2}{*}{ 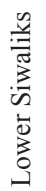 } & uppermember & 1300 & $\begin{array}{l}\text { Medium- to coarse-grained, grey sandstone alternates with bioturbated, variagated to dark } \\
\text { grey mudstone. "pepper and salt" texture sandstone are rarely found (sst>mst). }\end{array}$ \\
\hline & lower member & $300+$ & $\begin{array}{l}\text { Fine-grained, calcareous, greenish grey sandstone interbeds with bioturbated, variegated } \\
\text { mudstone (mst }>>\text { sst). }\end{array}$ \\
\hline
\end{tabular}

Sandstone beds are massive and occasionally rippled. Trough-cross bedded and ribbon-shaped sandstone beds are rare. Some of these sandstones occur as broad, isolated or overlapping ribbons with lateral accretionary architecture, which are also found in thick sandstone beds in the area. Calcareous nodules are well observed on the upper surfaces of finegrained sandstone beds, and also occasionally in mudstones. The sole of sandstone beds is flat or slightly eroded. Ripple laminations, raindrop imprints, mudcracks and trace fossils are commonly preserved in the sandstone beds. The facies association (FA1) is developed in the lower member of the Lower Siwaliks.

\section{Interpretation}

The facies association (FA1) is thought to be product of a fine-grained meandering system due to presence of bioturbated, variegated and thick bedded mudstone beds $(\mathrm{Fm})$, of calcareous nodules $(\mathrm{P})$, abundance of trace fossils in fine-grained sandstone beds. Significant amount of paleosols (P), with imprint of raindrops suggests the presence of extensive flood plain deposits of the meandering river. Dominance of mudstone and lateral accretionary architectures of sandstone are interpreted as indication of the existence of high sinuosity meandering river system. The rippled (Sr) and sheet-like sandstone beds interbedded within mudstone beds $(\mathrm{Fm}, \mathrm{Fl})$ represent crevasse splay deposits. Occurrence of the mudstone at the top of the fining-upward succession represents deposition occurring at calm condition (Nakajima 1982).

\section{Facies Association (FA2)}

The facies association (FA2) is medium- to coarsegrained, grey sandstone ( $\mathrm{St}, \mathrm{Sp}, \mathrm{Sr}$ ) interbedded with thinly layered muddy sandstone (Sh) and variegated to dark grey mudstone (Fm, Fl, Fsm). This facies association is also represented frequently by multiple accumulated sequences of mudstone and sandstone, which preserves ripple lamination $(\mathrm{Sr})$ and climbing ripples. Sandstone exceeds mudstone. Fine-grained sandstone beds are generally very thin ( 0.5 to $2 \mathrm{~m}$ thick), and massive in places, and have a sheet-like geometry. They are massive to rippled, and occasionally grade into overlying mudstones or grade from underlying mudstones. The coarse-grained sandstones reach up to $4 \mathrm{~m}$ in thickness showing trough cross-stratifications (St), and are frequently ribbon-shaped with lateral accretionary architecture. The fine-grained sandstone beds are commonly multistoried, whereas the coarser ones are frequently 
Table 3 Description and interpretation of the FA-facies association along the Kankai River section, East Nepal.

\begin{tabular}{|c|c|c|c|c|c|c|}
\hline $\begin{array}{c}\text { Facies } \\
\text { Association }\end{array}$ & $\begin{array}{l}\text { Dominant } \\
\text { lithofacies } \\
\text { types* }\end{array}$ & $\begin{array}{l}\text { Minor } \\
\text { lithofacies } \\
\text { types* }\end{array}$ & $\begin{array}{c}\text { Characteristic } \\
\text { architectural } \\
\text { element** }\end{array}$ & $\begin{array}{l}\text { Dominant } \\
\text { Geometry }\end{array}$ & $\begin{array}{c}\text { Stratigraphic units of } \\
\text { the Kankai River area } \\
\text { east Nepal }\end{array}$ & $\begin{array}{l}\text { Depositional } \\
\text { Environment }\end{array}$ \\
\hline FA1 & $\begin{array}{l}\mathrm{P}, \mathrm{Fr}, \mathrm{Fm}, \mathrm{Sr} \\
\text { Fl, Fsm }\end{array}$ & St, Sr & $\begin{array}{l}\text { FF, SB, LA } \\
>\text { LS }\end{array}$ & sheet, ribbon & $\begin{array}{l}\text { lower member of } \\
\text { the Lower Siwaliks }\end{array}$ & $\begin{array}{l}\text { Fine-grained } \\
\text { meandering system }\end{array}$ \\
\hline FA2 & $\begin{array}{l}\text { St, Sr, Fl, Fm } \\
\text { Fr, P }\end{array}$ & $\begin{array}{l}\text { Fsm, Ss, Sp } \\
\text { Sh }\end{array}$ & $\begin{array}{l}\text { LA, FF, SB } \\
>\text { DA }\end{array}$ & sheet, massive & $\begin{array}{l}\text { upper member of } \\
\text { the Lower Siwaliks }\end{array}$ & $\begin{array}{l}\text { Flood flow-dominated } \\
\text { meandering system }\end{array}$ \\
\hline FA3 & $\begin{array}{l}\text { St, Sr, Sp, Ss } \\
\text { Sh }\end{array}$ & $\begin{array}{l}\text { Fsm, Fl, P } \\
\text { Gt }\end{array}$ & $\begin{array}{l}\mathrm{DA}, \mathrm{LA}, \mathrm{FF} \\
\mathrm{SB}\end{array}$ & sheet & $\begin{array}{l}\text { lower member of the } \\
\text { Middle Siwaliks }\end{array}$ & Sandy meandering system \\
\hline FA4 & $\begin{array}{l}\mathrm{St}, \mathrm{Sr}, \mathrm{Sp}, \mathrm{Ss} \\
\mathrm{Sh}\end{array}$ & $\begin{array}{l}\text { Fl, Fsm, Gt } \\
\mathrm{P}\end{array}$ & $\begin{array}{l}\text { SB, DA, } \\
>\text { LA, HO, FF }\end{array}$ & sheet, ribbon & $\begin{array}{l}\text { middle member of the } \\
\text { Middle Siwaliks }\end{array}$ & $\begin{array}{l}\text { Deep sandy } \\
\text { braided system }\end{array}$ \\
\hline FA5 & $\begin{array}{l}\text { St, Sp, Fms } \\
\text { Sr }\end{array}$ & Fl, P, C & $\begin{array}{l}\text { DA, FF, SB } \\
>\text { LA }\end{array}$ & sheet & $\begin{array}{l}\text { upper member of the } \\
\text { Middle Siwaliks }\end{array}$ & Shallow braided system \\
\hline FA6 & Gp, Gt, Gh & $\begin{array}{l}\text { St, Ss, Sr } \\
\text { Fms, Gmm }\end{array}$ & $\begin{array}{l}\mathrm{GB} \\
>\mathrm{SB}, \mathrm{DA}, \mathrm{HO}\end{array}$ & sheet & $\begin{array}{l}\text { lower member of the } \\
\text { Upper Siwaliks }\end{array}$ & Gravelly braided system \\
\hline FA7 & $\begin{array}{l}\mathrm{Gp}, \mathrm{Gh}, \mathrm{Gcm} \\
\mathrm{Gmm}, \mathrm{Gmg}\end{array}$ & $\begin{array}{l}\text { Gt, St, Ss } \\
\text { Sr, Fms }\end{array}$ & $\begin{array}{l}\mathrm{SG}, \mathrm{GB} \\
>\mathrm{DA}\end{array}$ & sheet, & $\begin{array}{l}\text { upper member of the } \\
\text { Upper Siwaliks }\end{array}$ & $\begin{array}{l}\text { Debris flow-dominated } \\
\text { braided system }\end{array}$ \\
\hline
\end{tabular}

*Classification from Miall (1977, 1996). ** CH recognised in all facies associations. Classification from Miall (1985, 1996).

isolated. Thickness of the fine sandstone (Sh) beds ranges from 0.4 to $2 \mathrm{~m}$, some of the coarser sandstone beds are about $10 \mathrm{~m}$ thick, whereas mudstone beds are 1 to $2 \mathrm{~m}$ thick. Fining upward succession from the coarser sandstone to mudstone is clear. The thickness of such successions is 5 to $7 \mathrm{~m}$ beginning from coarse-grained sandstone to mudstone. The sole of sandstone beds is commonly slightly eroded to flat. Bioturbation and paleosols are less than those in the FA1-facies association. FA2-facies association is found in the upper member of the Lower Siwaliks.

\section{Interpretation}

The facies association, FA2 belongs to a flood flow-dominated fine-grained meandering river system. Repeated occurrence of thin layers of muddy sandstone (Sh) beds within fine- to coarse-grained sandstone is interpreted to have formed by successive flood flows. Laminated sandy mudstone (Fl) and fine-grained sandstone $(\mathrm{Sr})$ represent depositions from suspension and weak currents. Climbing ripples indicate gradual decrease in the velocity of flood flow. Coarse-grained sandstone (St) with lateral accreted architectures reflects bedload deposits of the meandering channels, whereas sheet-like geometry of finer grained sandstone beds reflects origin to the vertical aggradation by flooding. Interbedded paleosols (P) with laminated fine- to medium-grained sandstone beds indicate the seasonal or long-term drying out on the flood plain.

\section{Facies Association (FA3)}

The facies association (FA3) is represented by thick bedded, medium- to coarse-grained sandstone associated with dark grey mudstone and muddy sandstone. Dark grey mudstone (Fl, Fsm) beds are thin and are frequently minor to sandstone. Mediumto coarse-grained sandstone beds represent channel deposits and have trough cross-stratification (St), minor planar cross-stratification $(\mathrm{Sp})$, which occasionally forms both lateral and down accretional architectures. The muddy sandstones, commonly interbedded within the mudstones, have a multistoried, sheet-like geometry, and some of them contain ripples (Sr). Thinly layered muddy sandstone (Sh) beds interbedded with mudstone with sheet-like geometry sometimes exhibit ripples, as well as convolute beddings. The basal contact of each fluvial succession is erosional. Sandstone beds are generally 1 to $3 \mathrm{~m}$ thick and increase up to $5 \mathrm{~m}$, and mudstone beds are 0.5 to $2 \mathrm{~m}$ thick. The fining upward successions (5 to $10 \mathrm{~m}$ thick) are conspicuous and common. The lower member of the Middle Siwaliks exhibits the facies association, FA3.

\section{Interpretation}

The facies association, FA3 was also produced by 
a sandy meandering river system with flood flow dominant deposits. The evidence for this is the existence of lateral accreted cross-stratified sandstone and multiple muddy sandstone beds. The former beds suggest depositsion of bedload by high sinuosity channel flow, while the latter beds were formed by crevasse splays. The essential differences between the FA2 and FA3-facies associations are in the predominance of finely laminated mudstone beds (Fl) and fine rippled sediments ( $\mathrm{Sr}$ ) in FA2. This indicates a slight increase in discharge of the rivers from FA2 to FA3 facies.

\section{Facies Association (FA4)}

The facies association, FA4 is characterized by the presence of thick bedded, coarse- to very coarsegrained sandstone, sandstone and dark grey mudstone beds. Here, the proportion of mudstone beds is less than in FA3. Large-scaled trough cross-stratification (St) is well preserved in the sandstone beds. These multi-storied beds generally have sheet like geometry on an outcrop scale, although down accretions and lateral accretions with uncompleted ribbon shapes are also recognized. Coarse- to very coarse-grained sandstone and pebbly sandstone beds sometimes form downstream accretionary and lateral accretionary architectures. The thickness of individual sandstone beds ranges from 1 to $5 \mathrm{~m}$, and pebbly sandstone beds are about 0.5 to $3 \mathrm{~m}$. Pebbly sandstone beds have sheet-like geometry. Rounded to subrounded pebbles in these sandstone beds are derived from Lesser Himalayan rocks. Majority of the clasts are quartzite with 1 to $6 \mathrm{~cm}$ in diameter. The maximum size of mud clasts found in sandstone beds is about $15 \mathrm{~cm}$ along its long axis. The fining upward sequences ( 3 to $5 \mathrm{~m}$ thick) are distinct, which starts from pebbly sandstone bed with basal erosional surface. The thickness of bedload sediments consisting of coarse- to very coarse-grained sand and pebbly sand which forms the basal parts of the fining upward sequences commonly ranges between 4 and $10 \mathrm{~m}$. The FA4-facies association is developed in the middle member of the Middle Siwaliks.

\section{Interpretation}

The FA4-facies association is considered to have deposited by a deep sandy braided river system evidenced by the great volume of bedload sandstone with downstream and lateral accretionary architecture. Existence of intraformational mudclasts at the bottom of each fluvial succession suggests bank-cut materials produced during lateral migration of the channel. Common occurrence of thick fining upward sequences and presence of thick units of sandstone (St, Sp) and pebbly sandstone beds with erosional bases suggest the existence of deep channel flows.

\section{Facies Association (FA5)}

The FA5-facies association is identified by the presence of thick bedded, coarse- to very coarsegrained sandstone beds with subordinate pebbly sandstone and dark grey mudstone beds. FA5-facies components are essentially similar to those of facies (FA4) except in the presence of trough stratified gravel (Gt) beds and occurrence of thicker sandstone and pebbly sandstone beds. Coarse- to very coarsegrained sandstone and pebbly sandstone beds are trough $(\mathrm{St})$ and planar $(\mathrm{Sp})$ cross-stratified and show multiple accumulation. Some sandstone beds exhibit planar cross-bedded, and multi-storied, others are trough cross-bedded and multi-storied. Most multistoried sandstones have sheet-like geometry, in which down accretionary architectures are frequently observed. The sandstone and pebbly sandstone beds invariably show erosional bases. Ripple laminated and plane-stratified sandstone beds are frequently observed in the upper part of thick-bedded sandstones. However, plane-stratified beds are frequently associated with large scale cross-stratification, and are rarely combined with ripple beds. Downstream accretionary architecture is occasionally found in these units. Paleocurrent directions show little dispersion. Typical characteristic feature of this facies association is the rare occurrence of weakly developed fining upward succession. Thickness of each fining upward succession from coarse-grained sandstone or pebbly sandstone to mudstone ranges from 5 to 10 $\mathrm{m}$. This facies association is found in the upper member of the Middle Siwaliks.

\section{Interpretation}

The facies association (FA5) was developed by a shallow sandy braided river system. Less distinct fining upward successions, sheet-like geometry of 
sandstone and pebbly sandstone, the development of planar stratification (Sp) imply a shallower fluvial system. Multiple accumulations of planar crossstratified coarse-grained sandstone beds with a small dispersion in paleocurrent directions are the evidence of the shallow sandy braided river system. The combination of large-scale cross-stratification and plane-stratification indicates that the beds must have formed under upper flow regime.

\section{Facies Association (FA6)}

The facies association (FA6) is characterised by presence of thick bedded, clast supported and wellsorted conglomerate, subordinate lenses of reddish brown sandstone and dark grey mudstone. Almost all the clasts are pebble- or cobble-sized, rounded to subrounded in shape and derived from Lesser Himalayan terrain. Planar cross-stratifications (Gp) are well preserved but trough cross-laminations (Gt) are poorly developed in the conglomerates. Imbrication of the clasts is apparent. The conglomerates are 5 to $15 \mathrm{~m}$ thick, while the interbedded sandstone and mudstone beds range from 0.5 to $1 \mathrm{~m}$ in thickness. Fining upward sequence is indistinct due to the presence of numerous erosional surfaces. The paleocurrent directions measured from the imbricated gravels do not show scatter. FA6facies association is well developed in the lower member of the Upper Siwaliks.

\section{Interpretation}

The facies association (FA6) suggests that the sediments were deposited by gravelly braided river system as evidenced by the presence of widespread bedload gravel clasts, and uniformity in paleocurrent direction. Numerous erosional surfaces and predominance of conglomerate over other rock types may imply that the river system was relatively shallow and/or having unstable channels.

\section{Facies Association (FA7)}

Facies association (FA7) is the coarsest facies association composed of dominance of poorly sorted angular to subangular shaped, muddy matrix supported boulder conglomerates (Gms), have loose packing, and occasionally inverse grading. Imbrications are not prominent. Many of boulder-sized sandstones are derived from the Lower Siwailks other clasts are derived from the Lesser and Higher Himalayan rocks. Generally subrounded to subangular shaped clast supported well sorted pebble- to cobble conglomerates $(\mathrm{Gm})$ similar to those in FA6 subordinate with grey sandstones $(\mathrm{St})$ and dark grey to brownish grey mudstone (Fm) with no sharp bases were observed. $\mathrm{Gm}$ facies have sheet geometry. The conglomerate beds range from 5 to $12 \mathrm{~m}$ in thickness, whereas sandstone and mudstones are less than $2 \mathrm{~m}$ thick. Upward fining successions are cryptic, but may be less than $20 \mathrm{~m}$ thick. Commonly increased clast sizes are directly observed toward top of its stratigraphic position. The maximum size of the sandstone boulders is upto $1 \mathrm{~m}$ in its long axis diameter whereas generally the clast sizes are 15 to $25 \mathrm{~cm}$ in its diameter. The facies association associates in the upper member of the Upper Siwaliks.

\section{Interpretation}

Poorly sorted character and clast supported boulder conglomerates (Gms facies), muddy matrix and disorganized clasts arrangement or an inverse grading are thought to be the products of rapid deposition, which took place in proximal fluvial channels subjected to the debris flows. Inverse graded, massive conglomerate beds are interpreted as the sieve deposits. Presence of thick bed of dark grey mudstone beds $(\mathrm{Fm})$ is represented as the flooding materials. Wellsorted pebble- to cobble conglomerates (Gm facies) deposits from the bedload of gravelly river system. Sharp contact beds and clast-supported conglomerate reflect the formation of this facies association by high strength debris flows. So, FA7 is considered as the deposits of a debris flow-dominated braided system. Generally, these systems are observed in gravelly alluvial fan systems.

\section{DEPOSITIONAL PROCESS}

Five types of fluvial styles are recognized during the sedimentation period of the Siwalik Group in the Kankai River section. The earliest stage of the Siwalik sediment deposition began in a fine-grained meandering river system belonging to the FA1- facies association as described above. During this stage evidence of a long-term exposure of the flood plain 
and back swamp deposits is found. The second stage represented by the FA2 and FA3-facies associations is a fluvial environment with dominant assemblages of flood and crevasse splay sediment deposition. These facies associations indicate that the sedimentation took place in a flood flow-dominated meandering river systems. The third stage with the FA4 and FA5- facies associations is represented by deposits formed by a sandy braided river system as evidenced by the presence of thick bedded, coarseto very coarse-grained sandstone beds. During the fourth stage the fluvial system changed into a gravelly braided river system characterised by the FA6-facies association, which is distinguished from previous facies mainly by abrupt increase in sediment grain size. Lastly, the debris flow-dominated braided river system was developed. The FA7-facies association is characterised by poorly sorted boulder-sized and well-sorted gravel beds and pebble- and cobble-sized, massive gravel beds. The former were formed by debris flow, whereas the latter represent bedload current deposits. Such facies associations are generally found in an alluvial fan setting.

In the study area, all the FA1 to FA6 facies associations can be observed in the southern belt whereas only the FA1 to FA3 facies associations are present in the northern belt. Thus, the deposition of Siwalik Group sediment started in a meandering to flood flow-dominated meandering river system, followed by a sandy braided, and finally ended in a gravelly braided river system.

Periods of changes in fluvial system along the Kankai River section cannot be estimated due to lack of the paleomagnetic age. The flood flow-dominated meandering system occurred at $10.5 \mathrm{Ma}$ in the Bakiya Khola section, 9.9 Ma in the Tinau Khola section and 9.5 Ma in the Surai Khola section. It is assumed that the evolution of the flood flow-dominated meandering system began along the Kankai River section before $10.5 \mathrm{Ma}$ (Fig. 4).

The change from meandering to braided river system occurred at 9.0 Ma, 8.2 Ma and 6.5 Ma in the Bakiya Khola, Tinau Khola section and Surai Khola section. The development of the braided river system probably occurred during 8.2 to $6.5 \mathrm{Ma}$ in the Kankai River section. The gravelly fluvial system began during 3.0 Ma, 2.5 Ma, and 2.5 Ma in the Bakiya Khola, Tinau Khola and Surai Khola sections, respectively. In the Kankai River section, the gravelly braided river system developed during 2.5 to $3.0 \mathrm{Ma}$.

Willis et al. (1993) large-scale vertical sediments variations reflects change in the rate of the sediment input to the basin over time scales. Variations are related to the tectonism. Deposition rates and shifting position of the river system within the basin responded more quickly to change in the basin subsidence rate, whereas the increase proportion of sandstone bodies and increase in the flood plain lagged behind. It reveals that intensification of the monsoon climate was accomplished by a decrease in mechanical weathering. These effects on decrease in mechanical weathering could be due to reduction in tectonic activity and the dense plant covers (Burbank 1992). According to previous studies and this study indicate that the monsoon season started around 11 to $10 \mathrm{Ma}$ and well developed around 7.0 $\mathrm{Ma}$, and the development of the monsoon season intimately related to both evolution of fluvial styles and the uplift of the Himalayan-Tibetan Plateau Range.

Evolution of fluvial system in this study has a few apparent events such as flooding domination, changing from meandering to braided river system, and the appearance of gravel clasts. Monsoon development and uplift of Himalayan-Tibetan Plateau Range have also several aspects such as precipitation, location of thrust movements, the elevation of the HimalayanTibetan Plateau, and others. We have to fully clarify the major controlling factor on each evolutional event in near future.

\section{CONCLUSIONS}

On the basis of the lithological characteristics, the Siwalik Group in the Kankai River area is divided into three units: the Lower, Middle and Upper Siwaliks. The Lower and Upper Siwaliks are further subdivided into lower and upper members on the basis of relative thickness and ratio of the sandstone and mudstone beds for former unit whereas the clast size and thickness of the conglomerate and constituent of the Siwalik sandstone boulders for the later unit. The Middle Siwaliks is subdivided into the lower, middle and upper members based on thickness of sandstone beds. 
Seven types of facies associations are recognised. These facies associations are closely related to the lithostratigraphic units. The sediments of the lower member of the Lower Siwaliks are products of a finegrained meandering system. The upper member was formed by the flood flow-dominated meandering system. In contrast, the Middle Siwaliks is interpreted to result from deposits by a sandy meandering, deep sandy braided, and the shallow sandy braided systems, in lithologically ascending order. The sediments of the lower member of the Upper Siwaliks were deposited by the gravelly braided system, whereas those of the upper member owe to the debris flowdominated braided system.

The change in fluvial style from meandering to braided system may be intimately related to the onset of Asian Monsoon and the uplift of the HimalayanTibetan Plateau Range. Sedimentation of the Siwalik Group is the result of the collision of the Indian and Eurasian plate. Due to the development of the Main Central Thrust (MCT) and Main Boundary Thrust (MBT), upheaval of the northern part contributed to deposition in the Siwalik basin.

\section{ACKNOWLEDGEMENTS}

I would like to thank K. Takayasu (Shimane University, Japan), K. Arita (Hokkaido University, Japan), B. N. Upreti (Tribhuvan University, Nepal), M. P. Sharma (Tribhuvan University) and V. Dangol (Tribhuvan University) for their valuable suggestions. This study was supported by a Japanese Ministry of Education (JME) to grant-in aid (11691112; KN).

\section{REFERENCES}

Appel, E., Rosler, W., and Corvinus, G., 1991. Magnetostratigraphy of the Miocene-Pleistocene Surai Khola Siwaliks in west Nepal. Geophys. J. Int., v. 105, pp. 191-198.

Auden, J. B., 1935. Traverses in the Himalaya. Rec. Geol. Surv. India, v. 69(2), pp. 123-167.

Burbank, D. W., 1992. Cause of recent Himalayan uplift deduced from depositional patterns in the Ganesbasin, Nat., v. 357, pp. 680-683.

Cande, S. C. and Kent, C., 1992. A new geomagnetic polarity time scale for the late Cretaceous and Cenozoic. J. Geophys. Res., v. 97, pp. 13917-13952. Corvinus, G. and Nanda, A. C., 1994. Stratigraphy and palaeontology of the Siwalik Group of the Surai Khola and Rato Khola in Nepal. N. J. Geol. Palaeont. Abh., 191, Stuttgart, Marz, pp. 25-68.

Dhital, M. R., Gajurel, A. P., Pathak, D., Paudel, L. P., and Kizaki, K., 1995. Geology and structure of the Siwaliks and Lesser Himalaya in the Surai Khola-Bardanda area, mid Western Nepal. Bull. Dept. Geol., Tribhuvan Univ., v. 4, special issue, pp. 1-70.

Gautam, P. and Appel, E., 1994. Magnetic polarity stratigraphy of Siwalik Group sediments of Tinau Khola Section in west-central Nepal, revisited. Geophys. J. Int., v. 117, pp. 223-234.

Gautam, P. and Fujiwara, Y., 2000. Magnetic polarity Stratigraphy of Siwalik Group sediments of the Karnali River section in Western Nepal. Geophys. Jour. Int., vol. 142, pp. 812-824.

Glennie, K. W. and Ziegler, M. A., 1964. The Siwaliks formation of Nepal. International Geol. Congr., 22 Sess. Rep. Pt., 25, pp. 82-95.

Hagen, T., 1969. Report on the Geological Survey of Nepal (preliminary reconnaissance). Denkschr. Schweiz. naturf. Gesell., v. 86 (1), pp. 1-185.

Harrison, T. M., Copeland, P., Hall, S. A., Quade, J., Burner, S., Ojha, T. P., and Kidd, W. S. F., 1993. Isotopic preservation of Himalayan/Tibetan uplift, denudation, and climatic histories in two molasse deposits. J. Geol., v. 101, pp. 157-175.

Hisatomi, K. and Tanaka, S., 1994. Climatic and environmental changes at 9 and $7.5 \mathrm{Ma}$ in the Churia (Siwalik) Group, west-central Nepal. Him. Geol., v. 15, pp. 161-180.

Khan, I.A., Bridge, J.S., Kappelman, J., and, Wilson, R. 1997. Evlution of Miocene fluvial environment, eastern Potwar platau, nortern Pakistan, Sediment., V. 44(2), pp. 349-368.

Miall, A. D., 1978. Lithofacies types and vertical profile models in braided river: A summary. In: Fluvial Sedimentl., A. D. Miall (ed.), Mem. Can. Soc. Petrol. Geol. Calgary, v. 5, pp. 597-904.

Miall, A. D., 1985. Archtitectural-element analysis: a new method of facies analysis applied to fluvial deposits. Earth Sci. Rev., v. 22, pp. 261-308.

Miall, A. D., 1996. The geology of fluvial deposits, Sedimentary facies, Basin Analysis,960p.

Nakajima, T., 1982. Sedimentology and Uranium prospecting of the Siwaliks in western Nepal. Bull. Geol. Surv. Japan, v. 33 (12), pp. 593-617.

Nakayama, K. and Ulak, P. D., 1999. Evolution of the fluvial style in the Siwalik Group in the foothills of Nepal Himalaya. Sediment. Geol., v. 125, pp. 205-224.

Ojha, T. P, Butter, R. F., Quade, J., DeCelles, P. G., Richards, D., and Upreti, B. N., 2000. Magentic polarity strarigraphy of the Neogene Siwalik Group a Khutia Khola, far western Neapl, Geol.Scoc. Am. Bull., v. 112(3), pp. 424-434. 


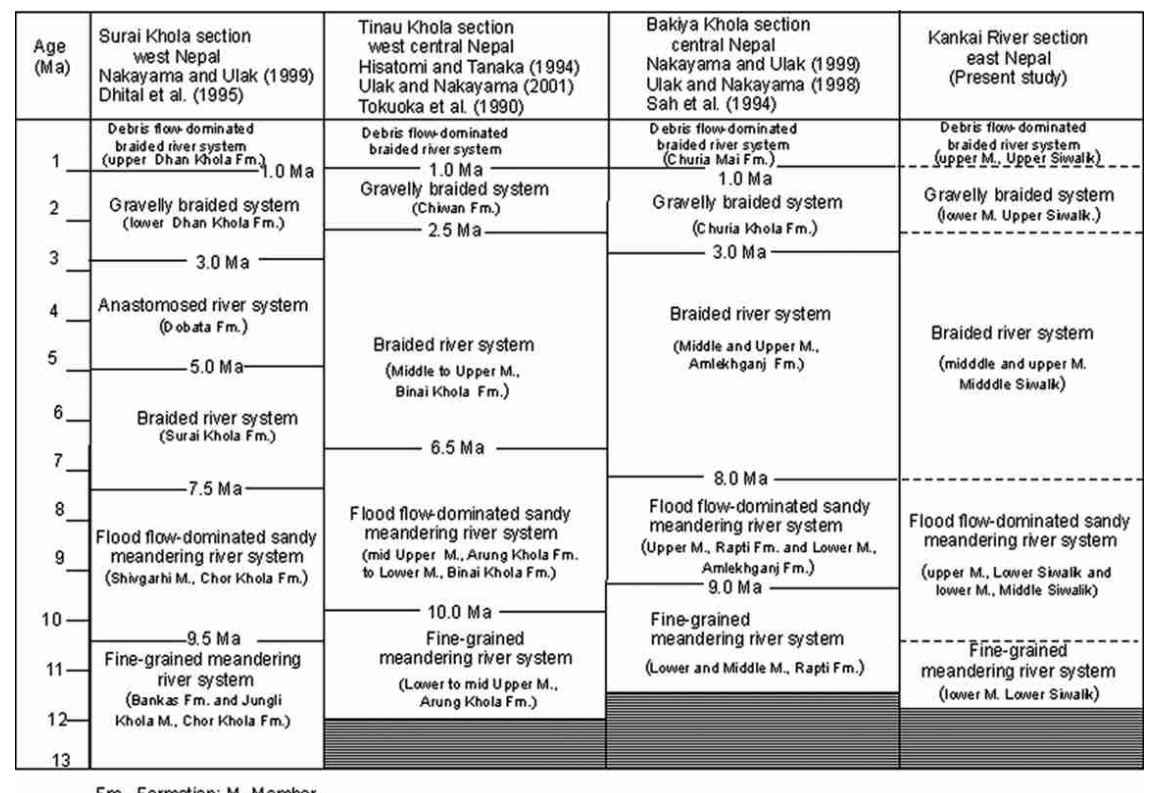

Fm. Formation; M.-Member

Fig. 4 Summary of timing for change in the river systems in the Siwalik Group of Nepal Himalaya.

Sah, R. B., Ulak, P. D., Gajurel, A. P. and Rimal, L. N., 1994. Lithostratigrphy of Siwalik sediments of Amlekhganj-Hetauda area, sub-Himalaya of Nepal. Him. Geol., v 15, pp. 37-48.

Sharma, C. K., 1973, Geology of Nepal. Educational Enterprises Pvt. Ltd., pp. 1-164.

Schelling, 1992. Tectonogstratigraphy and structure of the eastern Nepal Himalaya. Tecto., v. 11, pp.925-943.

Tokuoka, T., Takayasu, K, Hisatomi, K., Yamasaki, H., Tanaka, S., Konomatsu, M., Sah, R. B., and Roy, S. M., 1990. Stratigraphy and geologic structures of the Churia (Siwalik) Group of the Tinau-Binai Khola area, west-central Nepal. Mem. Fac. Sci. Shimane Univ., v. 24, pp. 71-88.

Tokuoka, T., Takayasu, K., Yoshida, M., and Hisatomi, K., 1986. The Churia (Siwalik) Group of the Arung Khola area, west-central Nepal. Mem. Fac. Sci. Shimane Univ., v. 22, pp. 135-210.

Tokuoka, T. and Yoshida, M., 1984. Some characteristics of Siwalik (Churia) Group in Chitwan Dun, Central Nepal. J. Geol. Soc. Nepal, v. 4, Special Issue, pp. 26-55.
Ulak, P. D., 2004. Evolution of fluvial system in Siwalik Group of Chatara-Barahakshetra area, East Nepal Himalaya. Jour. Nepal Geol. Soc., v. 30, pp.67-74.

Ulak, P. D. and Nakayama, K., 1998. Lithosratigraphy and evolution of the fluvial style in the Siwalik Group in the Hetauda-Bakiya Khola area, Central Nepal. Bull. Dept. Geol., v. 6, pp. 1-14.

Ulak, P. D. and Nakayama, K., 2001. Neogene fluvial systems in the Siwalik Group along the Tinau Khola section, west-central Nepal Himalaya. Jour. Nepal Geol. Soc. v. 25, pp., 111-122.

Willis, B., 1993. Evolution of Miocene fluvial systems in the Himalayan foredeep through a two kilometer-thick succession in northern Pakistan. Sed. Geol., v. 88, pp. 77-121.

Yoshida, M. and Arita, K., 1982. On the Siwaliks observed along some routes in Central Nepal. J. Geol. Soc. Nepal, v. 2, Special Issue, pp. 59-66.

Zaleha, M. J., 1997. Fluvial and lacustrine paleoenvironments of the Miocene Siwalik Group, Khur area, northern Pakistan, Sedimentol., v. 44(2), pp. 221-252. 